\title{
The Curriculum and Community Enterprise for Restoration Science Partnership Model
}

\author{
Lauren Birney ${ }^{1,}$, Denise McNamara ${ }^{2,3}$, Brian Evans ${ }^{1}$, Nancy Woods ${ }^{3}$ \& Jonathan Hill ${ }^{1}$ \\ ${ }^{1}$ School of Education, Pace University, New York, New York, USA \\ ${ }^{2}$ School of Education, The College of Staten Island, New York, New York, USA \\ ${ }^{3}$ New York City Department of Education, New York, New York, USA \\ *Correspondence: School of Education, Pace University, 1 Pace Plaza, New York 10038, USA. Tel: 212-346-1323. \\ E-mail: LBirney@pace.edu
}

Received: February 4, $2019 \quad$ Accepted: March 15, $2019 \quad$ Online Published: March 18, 2019

doi:10.5430/jct.v8n2p1

URL: https://doi.org/10.5430/jct.v8n2p1

\begin{abstract}
This paper identifies the complex interactions of a multi-member partnership and outlines the synergetic opportunities and challenges within the model. At the core of the partnership model is the restoration of the waterways surrounding New York City through the reestablishment of the oyster into New York Harbor. The overarching goal was to connect members of the community to their environment to increase social awareness and responsibility. Stewardship of the harbor through involvement of education, business, and private sectors increased the citizen science involvement of the community. The key to the success of this partnership model is the overlapping of roles and responsibilities as well as a strong "connector" serving to mediate the interactions among the stakeholders and enable the success of the partnership. The partnerships were dynamic and evolving blurring lines and responsibilities. Serendipitous outcomes enhanced partnership relationships and in turn, the efficacy of the project.
\end{abstract}

Keywords: partnerships, community, environmental science, restoration, STEM, citizen science, curriculum

“Alone we can do so little; together we can do so much.” Helen Keller

\section{Introduction}

Connections among the private, public, and nonprofit sectors are taking shape around the world to form unique and invaluable partnerships. These unions have been called the collaborative paradigm of the $21^{\text {st }}$ Century (Austin, 2000), and often serve to strengthen the unity among various members of the community as a happy consequence. This unity is commonly known as the "community partnership" and in simplest terms, means an affiliation of all levels of a community - universities, school districts, private business, and non-profit organizations (Tranel \& Gasen, 2003). The relative strength of each of the partners in the union brings about the key alliances in the project (Cash \& Moser, 2000).

In all partnerships, it is hoped that each of the partners contributes a well-developed skill set and through the amalgamation of these strengths, a synergy is created that both enhances the power of the project and enlightens each player to the potential for further collaboration. As with many community-based partnerships (Minkler, Vásquez, Tajik, \& Petersen, 2006), the partners demonstrate a strong commitment to collaborate with all stakeholders as well as the other partners in the project.

The term "partnership" can be traced back to medieval times in both Europe and the Middle East through the Latin for "portion" and Old French meaning "joint heir." However, arguably, partnerships had been formed as long as humans have cooperated together. The business sector has had a long-established understanding of the importance of strategic partnerships. Acquiring partners helps increase opportunities, diversify the alliance among members, and increases the skillset pool while strengthening a shared vision. Involving partnerships in most major endeavors is the norm. When undertaking a business venture or creating a cutting edge organization, one of the first essential 
undertakings is the deliberate and pragmatic selection of partners in the project. Although this has been a staple of corporate methodology, it is only relatively recently that the educational sector has begun to embrace this concept (Avallone, 2017).

It is not very common for the education sector to work alongside professionals in the business community as well as local, community-based organizations to enhance a student's success in school and possible future career pathways (Epstein, 2011). Lacking these necessary affiliations, there is a disconnection between the school and the community in which it is situated. School leaders should collaborate with the other members of their community to allow for an integration of local resources and services. These can strengthen and support the students by increasing learning opportunities as well as creating community awareness and responsibility in the students. In addition, these partnerships have the potential for skills acquisition that could lead to gainful employment. The success of partnerships lies in the ability to think strategically; to figure out the best effective work model from a talent and a cost perspective (Wagner, 2008). An even greater challenge is how to forge effective collaborative teams and work with people who come from vastly different backgrounds.

A common benefit of school-university partnerships is the potential to facilitate change. Some school-university partnerships are being developed to facilitate equity-minded school reform and shape pathways for students to higher education (Jones, Yonezawa, Ballesteros, \& Mehan, 2002). Others are formed to create a bond between the partners and the community in which it is located. Strong school-community partnerships depend on collaboration and communication to ensure success (Gross, Haines, Hill, Francis, Blue-Banning, \& Turnbull, 2015). Educational opportunities that derive from community-based learning take many forms. The National Research Council (2009) has categorized community-based educational models in the following manner.

Table 1. Community-Based Models and Their Characteristics

\begin{tabular}{ll}
\hline Model Type & Model Description \\
\hline $\begin{array}{l}\text { Academically-Based Community } \\
\text { Civic Education }\end{array}$ & $\begin{array}{l}\text { Connects the academic mission of colleges and universities with the } \\
\text { aspirations of the communities around them. } \\
\text { Aims to prepare competent and responsible citizens }\end{array}$ \\
Environmental Education & $\begin{array}{l}\text { Uses the school's surroundings and the community as its framework } \\
\text { within which the students construct their own learning (Leiberman \& } \\
\text { Hoody, 1998) }\end{array}$ \\
Ulaced-Based Learning & $\begin{array}{l}\text { Uses the unique history, environment, culture, and economy of a } \\
\text { particular place. }\end{array}$ \\
Integrates community service with academics
\end{tabular}

It seems apparent that for community-based learning to foster and grow, the elements of the entire community must be considered in the partnership. The students must be able to connect their educational environment with their physical environment to play an active role in both. "Education must connect subject matter with the places where students live and the issues that affect us all" (Melaville, Berg, \& Blank, 2001). One of the ways to ensure that this authentic and connected learning can take place is by leveraging strong community partnerships to provide real-world learning to students in middle and high schools (Gross, et al., 2015).

One such connection that is thriving in New York City is the Curriculum and Community Enterprise for New York Harbor Restoration Science (CCERS) project, which is funded through a National Science Foundation (NSF) grant (Award \#1440869) and began in 2014. As it approaches its fifth year, the project focuses on the reintroduction of oysters into the New York Harbor. Originally called the Billion Oyster Project (BOP), the pivotal focus of the project is to restore one billion oysters into New York Harbor by 2030. 


\section{The Unique Community That Is New York City}

New York City is the largest metropolitan areas in the United States (U.S. Census Bureau, 2016). It is one of the most linguistically diverse cities in the world with a foreign-born population of approximately $36 \%$ of the city's total population. During the decades of immigration to New York, many cultural groups initially settled in specific sections of the city. Although these areas have undergone several iterations as they evolved over the years, some sections have retained their ethnic individuality. For example, Little Italy has decreased in size because succeeding generations of Italian immigrants moved to other areas of the city or the suburbs. However, adjacently located Chinatown has retained its ethnic presence and has actually grown in geographic terms. Similarly, there are innumerable pockets of ethnic and cultural groups throughout the city even with the gentrification that has occurred.

Adding to the uniqueness of the city are the numerous and varied geographic nuances that are comprised within its 305 square mile borders. Each of New York's five boroughs is either an island unto itself (Manhattan and Staten Island), shares an island (Brooklyn and Queens), or is part of a peninsula (the Bronx). The geography differs from borough to borough and within each of the boroughs as well. The area of natural highest elevation in New York City is located on Staten Island (Todt Hill at 409 feet above sea level), and yet parts of Staten Island, Brooklyn, and Manhattan are less than 4 feet above sea level, a fact that was frighteningly realized during Super Storm Sandy in 2012. The Bronx is the only borough that is part of the North American mainland and Brooklyn and Queens are part of a massive moraine that formed at the end of the last Ice Age. The temperature between boroughs can vary by as must as $10^{\circ} \mathrm{F}$ and at any given time, it can be snowing in Brooklyn while Manhattan experiences clear, sunny skies. Because of these numerous inconsistencies, it is difficult to use the term "community" when referring to New York City as a whole. Instead, it might be more accurate to call New York City an assemblage of several communities.

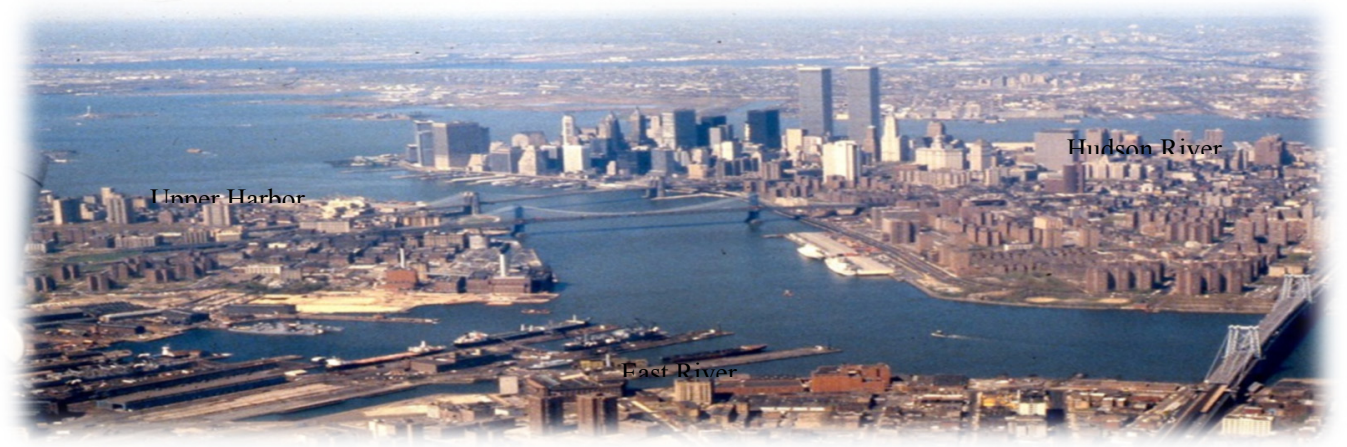

Figure 1. New York Harbor 1991 - The East River and the Hudson River Converge to Form Upper New York Harbor

However, New York's strength comes from the close community culture that exists throughout the city. The binding connection is through New York's magnificent harbor. New York City's harbor is one of the world's largest natural harbors, and is touches on each of the boroughs in the city. It is composed of both an inner and outer harbor and forms the New York-New Jersey Harbor Estuary, which was once teeming with wildlife. Although only a few geographic areas of the harbor have changed, the human impact cannot be understated. Nonetheless, the harbor is still host to a large variety of terrestrial and aquatic life though the numbers are drastically reduced. Fittingly then, at the core of the CCERS partnership, is this great harbor.

New York Harbor contained over 220,000 acres of oyster beds and hosted an overabundance of aquatics species and birds when Henry Hudson arrived in 1609. Although once known as the "Oyster Capital of the World," the harbor was victim to a triple threat - population growth, the Industrial Age, and the lack of conservation laws for many decades. These forces created a deadly environment for most of the wildlife, especially the Eastern oyster (Crassostrea virginica). By the 1820's, most of the New York oyster beds had been overharvested and could not keep up with the growing demands for the New York oyster (Kurlansky, 2007). The City Health Commissioner closed the few remaining oyster beds in 1927 and the industry dwindled to near extinction.

New York Harbor has begun to once again thrive with the reestablishment of the Eastern oyster, through the CCERS place-based environmental science education project. The primary function of the project is the restoration of the oyster is helping to purify the waters of this most important estuary. An adult oyster can filter as much as 50 gallons of water a day, removing pollutants by either consuming them or processing them into smaller, harmless components 
which are deposited on the bottom of the estuary. Of equal importance is the educational value that the project brings. The field experience at the Oyster Restoration Stations throughout the harbor has helped to overcome urban students disinterest in science and engages students in local area science experiences (Lim \& Calabrese-Barton, 2006). This place-based environmental education is helping to establish a sense of stewardship of the harbor among the middle school students from all five of the boroughs of New York.

\section{The Quintessential Partners in the STEM CCERS Project - It Takes a Village}

"It began when one curious kayaker, noting the occasional presence of an oyster in the bay waters of Brooklyn, wondered how to help restore them more fully" (Eldredge \& Horenstein, 2014)

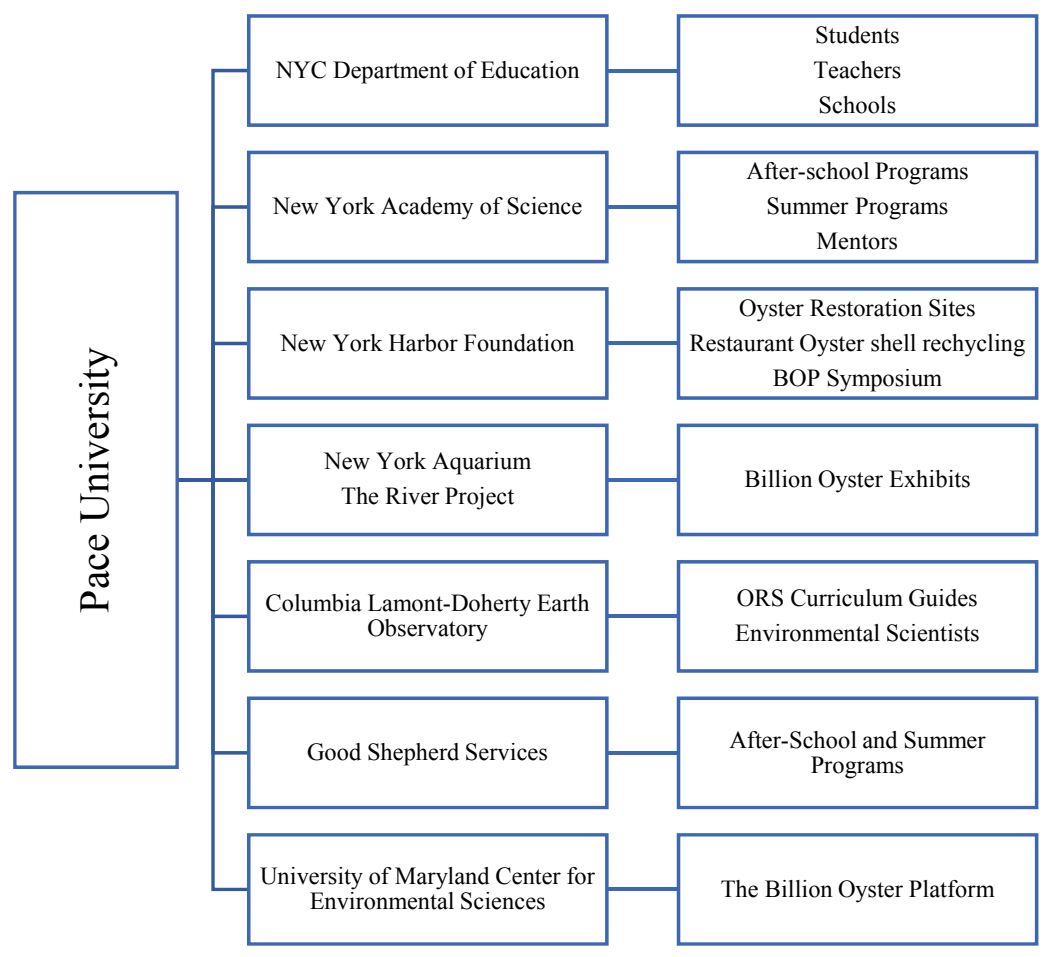

Figure 2. The Connector and the Connections

In his elegantly crafted first novel, The Tipping Point, Malcom Gladwell uses the term, "a biography of an idea" (Gladwell, 2000). His reference is to the treatment of contagious behavior, or epidemics among groups of individuals or communities when a thought or an idea is brought to the attention of the public. He states that for these epidemics to gain momentum and establish sustainability, people called connectors are critical. In the case of the CCERS partnership, Pace University is the connector. Although the interest of a kayaker created a spark, and a desire to change the landscape, it was the professors at Pace University who spearheaded the cross-sector partnership to create the CCERS partnership. As the evolution of this idea took form, key players at Pace University began to identify partnership opportunities among the stakeholders in New York City and recognized the value of strategic partners to the project. Although many of the partners had existed as solitary beacons of education, business and/or conservation and restoration, a unifying presence with a vision was needed to bring all of the constituents to the table. It was realized that successful partnerships must give partner relationships time to develop to fruition while respecting the differences and diversity among each member of the group. The partnership value to the project, involving the community as a whole was recognized and then aligned to the overarching vision and values of the entire project (Sanders, 2001). In a study on partnerships, Sanders stated that the major impediment to successful community-school partnerships is the lack of communication and strong leadership within each of the partnership organizations. In another similar study, it was found that in order to function as a partner, each organization must have a degree of organizational capacity to manage projects and budgets and establish manageable objectives in order to keep people involved (Chaskin \& Peters, 2000). Therefore, it was not only essential that the originator of the idea be able to oversee the entire project, individual members of the consortium must possess the same degree of management. Some researchers contend that the rhetoric of school-university partnerships differs from reality and 
partners cannot know the challenges that will be faced (Stephens \& Boldt, 2004) but the fervor with which each of the partners approached this project, along with their highly organized infrastructure became the key to the success of CCERS, hence, forth known as the STEM CCERS project.

There are several major partners in the CCERS Project and each serves a specific function within the overarching framework and in several cases have overlapping functions. Pace University has the lead role in the consortium, spearheading the project by fostering a professional learning community for teachers. The faculty who head the school-university partnership project designed a professional learning community for teachers, treating them as professionals and relying on their expertise to help create the activities that are the basis of the lessons and units. These activities are dynamic and are evolving based on the needs of the teachers and students (Bartholomew \& Sandholtz, 2009). Not only do they help design the material, the New York City Department of Education middle school teachers, working in Title I funded schools, are also instructed in activities intended to engage their students in hands-on environmental STEM and restoration ecology in New York Harbor. Pace University also serves as the critical component to the first of five pillars in the project. Pillar I is the teacher education portion which includes computer science training, STEM career exploration, and curriculum development. Additionally, there are unique lectures by science experts from Columbia's Lamont-Doherty Earth Observatory and curriculum specialists from the New York Harbor Foundation and The River Project. The design and development of these activities emerged through the interests and the needs of the teachers (Bartholomew \& Sandholtz, 2009).

The New York City Department of Education is one of the most critical partners. The New York City Department of Education is the largest (1.1 million students; 1,843 schools) and most diverse (19.7\% students with disabilities; $74.0 \%$ economically disadvantaged) school system in the United States. The CCERS project is currently composed of 78 New York City public middle schools, 5,600 students, and 127 teachers. Its long-term objective is to engage every student in the city in the restoration and stewardship of New York Harbor. One of the primary functions of schools is to prepare students to create stronger communities (Michelli \& Keiser, 2005). One of the New York City Department of Education initiatives is educational equity throughout the system. The New York City public school system consists of $66.5 \%$ students of color. An area of education in which there is a marked dearth of diversity is in the STEM concentrations (Whittaker \& Montgomery, 2012). Equity in science learning occurs when individuals from diverse backgrounds participate in science as practiced in the established scientific community and centers on making science assessable, meaningful and relevant for diverse students by connecting their home and community cultures to science (National Research Council, 2009). Pillar II, the creation of a student-learning curriculum, is embedded in this partnership. In developing the student curriculum, it became apparent that the content would have to go well beyond just science. To stay true to the place-based, environmental restoration theme, multiple content areas such as mathematics, technology, history, and geography has to be included. The STEM curriculum that was developed allows the students to engage in trans-disciplinary(Note 1) learning tudents construct knowledge through hands-on, real-world experiences in the local community. This constructivist approach to the curriculum connects the classroom to the community and increases academic achievement, helps students develop stronger ties to the community, enhances students' appreciation for the natural world, and creates a heightened commitment to serving as active, contribution citizens (Sobel, 2005).

A third key partner is Columbia's Lamont-Doherty Earth Observatory. This institution not only serves as a provider of scientist expert guest lecturers, but partners in a number of invaluable educational learning services. Teachers and students visit the facility for environmental excursions and perform research on water quality, aquatic environments, and oyster restoration and preservation. Environmental scientists at the Lamont-Doherty Earth Observatory developed the Oyster Restoration Manual that is used by both teacher and students and therefore forms a segment of Pillar II as well.

The fourth core partner is the University of Maryland and is the key to Pillar III of the project, the digital platform. The platform now contains both data input from the teachers and their classes and lessons and units that have been designed by the scientists and the teachers in tandem (synergetic energy from the perspective of the estuary experts as well as the pedagogical experts). One of the primary functions of the platform is the collection and housing of the data pertaining to the harbor and its component parts, both abiotic and biotic. The digital platform is a versatile and adaptable infrastructure for stakeholders to conduct real-world STEM and policy research and education-in this case, on ecological restoration of New York Harbor-supported by youth citizen scientists and environmental advocates, research scientists, education professionals, and community members. The National Science Foundation task force on cyber-learning (NSF, 2008) recommends that a "platform perspective" should be instilled through shared, interoperable designs of hardware, software, and services - into NSF's cyber-learning activities. An effective platform should incorporate promising innovations from newly funded technology projects and offer fully tested and 
supported modules for use in classrooms. It should ensure that learning materials targeted for the platforms are widely useable and remain useable over time. Advances in technology are poised to meet these educational demands (Borgman, Abelson, Dirks, Johnson, Koedinger, \& Linn, 2008). The four basic and essential characteristics that any platform should have are interactivity, flexibility, scalability, and standardization (Silvertown, 2009). The CCERS platform houses components which address these essential characteristics while addressing the concern of educational demands and the integrity of the resources provided. A dynamic system, the platform contains the following subsections:

- Restoration, where the dashboard and the oyster restoration sites can be found

- Curriculum, where the lessons and units are found

- Research, containing posters and publications created by the students

- Community, listing all of the schools and community organizations involved in the project

- Metrics, providing a large amount of statistical information

- Events, containing a list of all of the upcoming events for the calendar year.

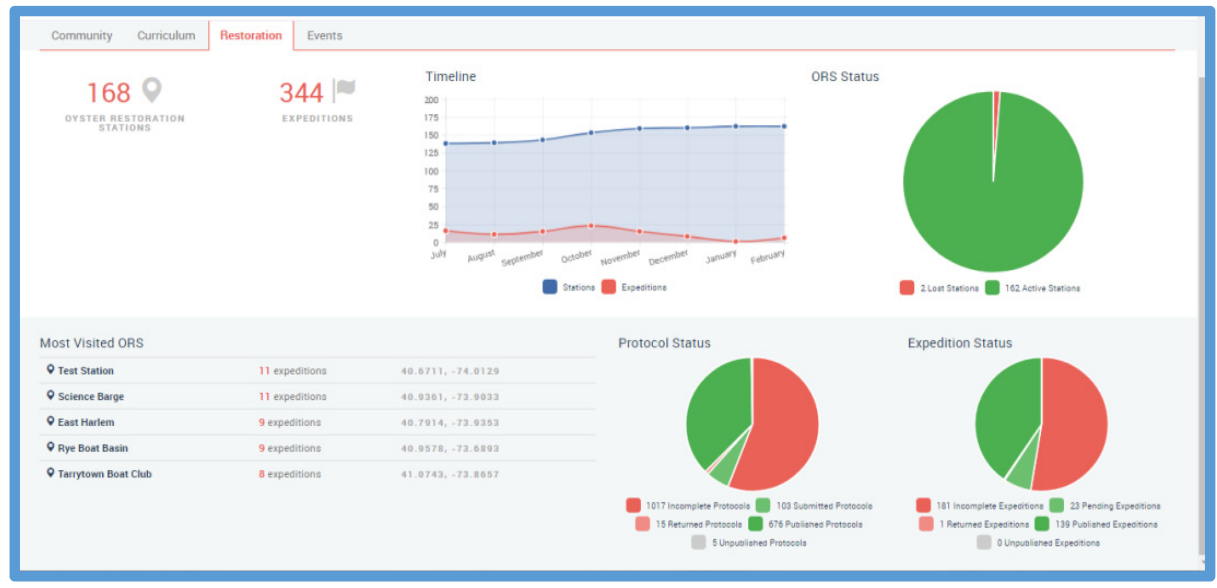

Figure 3. Restoration Tab on the Platform

The fifth primary partner in the CCERS project is the New York Harbor Foundation, which has as its mission to improve the access to, awareness and education about, and condition of New York Harbor The value of this partner cannot be overemphasized. The New York Harbor School, a maritime public high school located on Governors' Island, is funded through this non-profit organization and has unique offerings in CTE (Career \& Technical Education) programs in marine science. The school is the focal point for the CCERS project and is the nucleus for the Oyster Restoration Sites, reefs, and oyster shell collection facility. As well as being a major partner, the New York Harbor Foundation and its school are components of Pillar II of the STEM CCERS project.

The New York Academy of Science and Good Shepherd Services are vital partners in the after-school mentoring portion of the project. Schools benefit from the increased resources, supports, and relationships resulting from the development of trusting school-community partnerships (Gross, et al., 2015). Nowhere is this more evident than in the partnerships with the New York Academy of Science and Good Shepherd Services. These partners provide informal learning experiences for the students in both after-school and summer STEM programs and are the underpinnings of Pillar V. Research has shown that after-school programs enhance the personal and social skills of students including self-perception and communication skills that reduce problem behaviors (Durlak, Weissberg, \& Pachan, 2010). New York Academy of Science mentors collaborate with Good Shepherd Services to bring hands-on harbor restoration education to students in underserved neighborhoods. Topics such as oyster dissections, water sample testing, and the effects of water run-off among others are taught in an informal setting. During the summer, the students are treated to "Camp Restore" where they visit the aquaculture lab on Governors' Island and sail on the Pioneer, an 1885 schooner used to teach the students about environmental awareness. Research indicates that students who are engaged in real-world, hands-on science are more successful in science and have a deeper understand and appreciation of the content (Foley \& McPhee, 2008). 
Another two-pronged partnership of the STEM CCERS Project constitutes Pillar IV. Both the New York Aquarium and the River Project are science education and research facilities. Each has dedicated exhibits in oyster reef restoration. The River Project is located at Pier 26 in Tribeca and actively works at the restoration of the ecosystems in the New York-New Jersey Harbor Estuary and has installed a 4,000-gallon flow-through Oyster Reef Estuarium Exhibit (See Figure 4). Classes of students are invited to the site to take part in programs designed to educate, enlighten, motivate, and involves the students of New York City. The New York Aquarium, which was badly damaged in Super Storm Sandy, is developing a similar exhibit and will have an accompanying learning guide to aid the students in recognizing abiotic and biotic aquatic species native to the estuary.

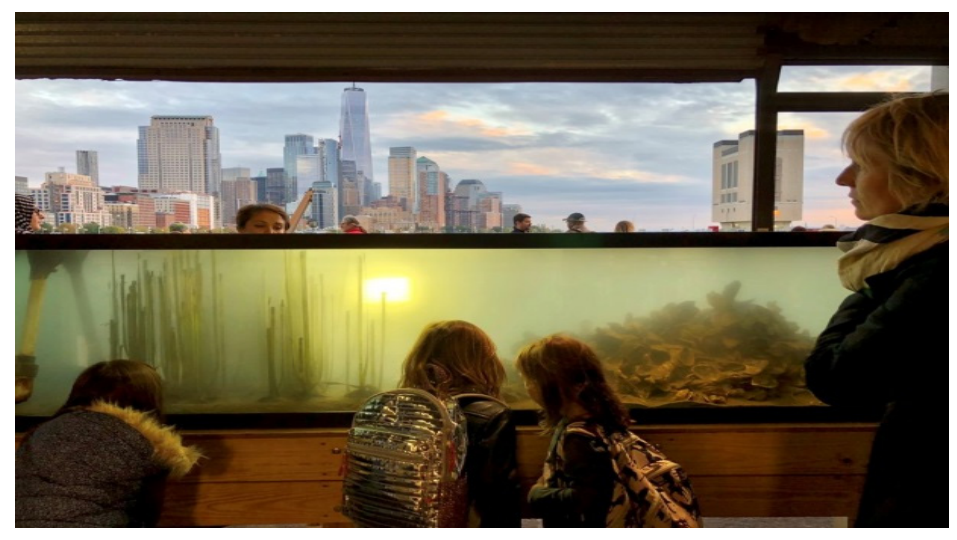

Figure 4. Oyster Reef Ecosystem Exhibit- The River Project

\section{The Extended Community Partnerships}

When the STEM CCERS project was envisioned, it was as an extension of the original Curriculum and Community Enterprise for Restoration Science (CCERS) partnership, more commonly known as The Billion Oyster Project (BOP). The project was a massive undertaking in both planning and coordinating all of the stakeholders who would become the primary partners in this effort. But as the project developed and grew, it was evident that this was just the beginning. For example, briefly mentioned earlier, there is an oyster shell collecting and recycling center on Governors' Island. Partnerships with NRG Arthur Kill Generating Station and the shell depot at the Exxon Mobil Greenpoint Campus have been established to manage the enormous number of oyster shells that are donated by more than 70 participating restaurants across New York City. The shells are processed and then reused to nurture the "spat" which will eventually develop into oysters.

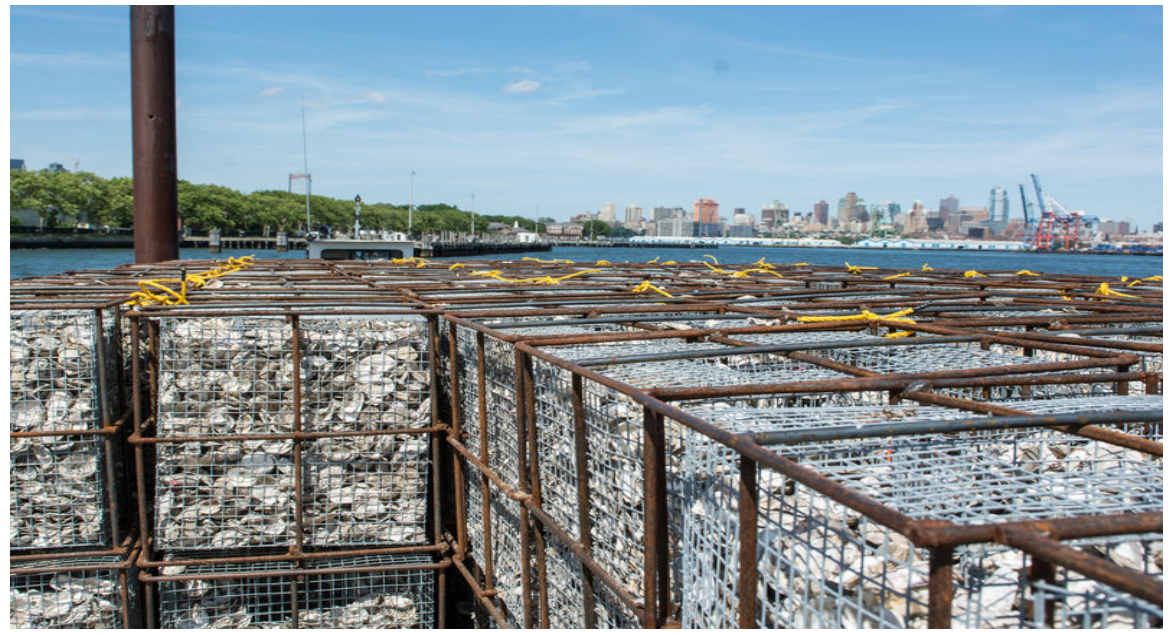

Figure 5. Thousands of Recycled Oyster Shells on the Shore of Governors' Island

The community partnerships that are involved in this project are both dynamic and evolving. The capacity threshold is elusive and as organizational allies in the community become cognizant of the STEM CCERS project and federal 
and not-for-profit funding continues to support the environmental restoration of the harbor, the two-pronged goal of creating citizen scientists as stewards of the harbor and populating the waters with a billion oysters seems within reach.

\section{Overall Impact}

Given all of the components of The Billion Oyster Project (BOP) and the STEM Curriculum and Community Enterprise for Restoration Science (STEM + CCERS), the effect of the combined projects on sectors of New York City is impressive. Each of the projects began with its own unique focus. The Billion Oyster Project's mission was to repopulate the harbor with a billion oysters and The STEM Curriculum and Community Enterprise for Restoration Science was focused on the educational potential of BOP. By combining the two and adding the New York City Department of Education, the projects had the potential of reaching thousands of public school students and transforming them into citizen scientists. The need for curriculum to be developed and resources created became evident so that the classroom and fieldwork components could be realized. Additional, out of classroom time was also added and the informal educational institutions developed additional resources and curriculum for the extended school day. The partnerships were dynamic and evolving blurring lines and responsibilities. Serendipitous outcomes enhanced partnership relationships as well as the projects themselves.

Much like the reintroduction of the grey wolf to Yellowstone National Park (Smith, Peterson \& Houston, 2003), the reintroduction of the eastern oyster into New York Harbor has the potential to change this estuary for the better. The community partnerships combining education, restoration and environmental stewardship has the potential for immeasurable opportunities in New York City.

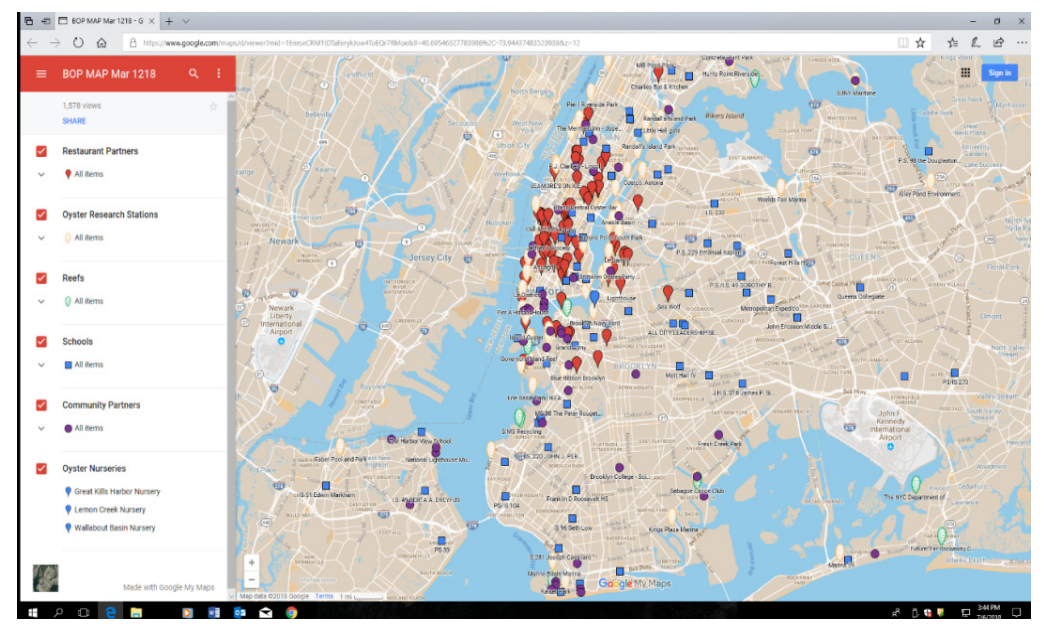

Figure 6. Culmination of All of the Schools, Restaurants, Oyster Restoration Stations, Reefs, Nurseries, and Community Partners in the Five Boroughs of New York City

\section{Implications for Further Research}

The focus of this paper was to highlight the need for a dynamic partnership relationship and constant fluidity in the roles that each partner played and the deliverables for which each was responsible. For some it was a challenge but for most, the goal of increasing the quality of the harbor through education and civic stewardship drove the project and ensured results. Devoting time to the infrastructure of the partnership organization and constant communication between and among all of the partners helped to ensure that there was a common goal for which to strive. This partnership model can also be seen as a microcosm of the city as well. Further work is needed to build capacity and to ensure sustainability of the project. 


\section{References}

Austin, J. E. (2000). Strategic collaboration between nonprofits and businesses. Nonprofit and Voluntary Sector Quarterly, 29(1), 69-97. https://doi.org/10.1177/089976400773746346

Avallone, A. (2017). It takes a village: Community partnerships for real-world learning, Education Week. Retrieved from

http://blogs.edweek.org/edweek/next_gen_learning/2017/12/it_takes_a_village_community_partnerships_for_re al-world learning.html

Bartholomew, S. S., \& Sandholtz, J. H. (2009). Competing views of teaching in a school-university partnership, Teaching and Teacher Education, 25(1), 155-165. https://doi.org/10.1016/j.tate.2008.07.001

Borgman, C. L., Abelson, H., Dirks, L., Johnson, R., Koedinger, K. R., \& Linn, M. C. (2008). Fostering learning in the networked world: The Cyber learning opportunity and challenge. Report of the NSF task force on cyber learning. Washington, DC. Retrieved from https:/www.nsf.gov/pubs/2008/nsf08204/nsf08204.pdf

Cash, D. W., \& Moser, S. C. (2000). Linking global and local scales: Designing dynamic assessment and management processes, Global Environmental Change, 10, 109-120. https://doi.org/10.1016/S0959-3780(00)00017-0

Chaskin, R. J., \& Peters, C. (2000). Decision making and action at the neighborhood level: An exploration of mechanisms and processes. Discussion Paper CB-23. Chicago, IL: Chapin Hall Center for Children.

Durlak, J. A., Weissberg, R. P., \& Pachan, M. (2010). A meta-analysis of after-school programs that seek to promote personal and social skills in children and adolescents. American Journal of Community Psychology, 45(3-4), 294-309. https://doi.org/10.1007/s10464-010-9300-6

Eldredge, N., \& Horenstein, S. (2014). Concrete jungle - New York City and our last best hope for a sustainable future, , Oakland, CA: University of California Press.

Epstein, J. L. (2011). School, family and community partnerships: Preparing educators and improving schools. Boulder, CO: Westview Press

Foley, B. J., \& McPhee, C. (2008). Students' attitudes towards science in classes using hands-on or textbook based curriculum. Paper presented at the meeting of the American Educational Research Association. New York, NY.

Gladwell, M. (2000). The tipping point: How little things can make a big difference. New York, NY: Little, Brown and Company.

Gross, J. M. S., Haines, S. J., Hill, C., Francis, G. L., Blue-Banning, M., \& Turnbull, A.P. (2015). Strong school-community partnerships in inclusive schools are "Part of the fabric of the school. We count on them." School Community Journal, 25(2), 9-34.

Jones, M., Yonezawa, S., Ballesteros, E., \& Mehan, H. (2002). Shaping pathways to higher education. Educational Researcher, 31(2), 3-11. https://doi.org/10.3102/0013189X031002003A

Kurlansky, M. (2007). The big oyster: History on the half shell. New York, NY: Random House.

Leiberman \& Hoody. (1998). Closing the Achievement Gap: Using the Environment as an Integrating Context for Learning. Paper presented at the State Education and Environmental Roundtable, San Diego, CA.

Lim, M., \& Calabrese Barton, A. (2006). Science learning and a sense of place in an urban middle school. Cultural Studies of Science Education, 1, 107-142. https://doi.org/10.1007/s11422-005-9002-9

Melaville, A., Berg, A. C., \& Blank, M. J. (2006). Community based learning: Engaging students for success and $\begin{array}{llll}\text { citizenship. } & \text { Partnerships/Community, } & \text { Retrieved }\end{array}$ https://digitalcommons.unomaha.edu/slcepartnerships/40

Michelli, N. M., \& Keiser, D. L. (2005). Teacher education for democracy and social justice. New York, NY: Routledge, Taylor \& Francis Group.

Minkler, M., Vásquez, V. B., Tajik, M., \& Petersen, D. (2008). Promoting environmental justice through community-based participatory research: The Role of community and partnership capacity. Health Education \& Behavior, 35, 119-138. https://doi.org/10.1177/1090198106287692

National Research Council. (2009). Learning science in informal environments: People, places, and pursuits. Washington, DC: The National Academies Press. https://doi.org/10.17226/12190 
National Science Foundation. (2008). Fostering learning in the networked world: The cyber-learning opportunity and challenge. Washington, DC: Report of the NSF Task Force on Cyber-learning.

Sanders, M. G., (2001). The role of "community" in comprehensive school, family and community partnership programs. The Elementary School Journal, 102(1), 19-32. https://doi.org/10.1086/499691

Silvertown, J. (2009). A new dawn for citizen science. Trends in Ecology and Evolution, 24(9), 467-471. https://doi.org/10.1016/j.tree.2009.03.017

Sobel, D. (2005). Place-based education: Connecting classrooms and communities. Great Barrington, MA: The Orion Society.

Stephens, D., \& Boldt, G. (2004). School/university partnerships: rhetoric, reality, and intimacy. Phi Delta Kappan, 85(9), 703-707. https://doi.org/10.1177/003172170408500912

Tranel, M., \& Gasen, K. (2003). Community partnerships: A sustainable resource for nongovernmental organizations. Retrieved from https://www.researchgate.net/publication/5036644

United States Census Bureau. (2016). 2018 population estimates. Washington DC: United States Census Bureau. Retrieved from https://www.census.gov/newsroom/press-kits/2018/pop-estimates-national-state.html

Wagner, T. (2008). The global achievement gap. New York, NY: Basic Books.

Whittaker, J. A., \& Montgomery, B. L. (2012). Cultivating diversity and competency in STEM: Challenges and remedies for removing virtual barriers to constructing diverse higher education communities of success. Journal of Undergraduate Neuroscience Education, 11(1), A44-A51. PMID: 23493445

\section{Note}

Note 1. As defined by the International Bureau of Education, a trans-disciplinary approach to education is an approach to curriculum integration, which dissolves the boundaries between the conventional disciplines and organizes teaching and learning around the construction of meaning in the context of real-world problems or themes.(International Bureau of Education, Geneva, Switzerland, http://www.ibe.unesco.org ) 